\title{
SEROPREVALENCE OF SOME INFECTIOUS DISEASES IN STRAY DOGS IN THE WIDER TERRITORY OF LESKOVAC CITY
}

\author{
Marija Manić ${ }^{1}$, Nataša Prokić 1 , Katarina \\ Gojković ${ }^{2}$, Goran Đorić ${ }^{2}$, Ana Vasić ${ }^{1 \star}$, \\ Jovan Marić ${ }^{1}$, Dragica Vojinović ${ }^{3}$, Bosiljka Đuričić ${ }^{1}$ \\ ${ }^{1}$ Faculty of Veterinary Medicine, University of Belgrade, Serbia \\ ${ }^{2}$ Veterinary ambulance "Đura vet", Leskovac, Serbia \\ ${ }^{3}$ Scientific Veterinary Institute of Serbia, Belgrade, Serbia
}

\section{Abstract}

Since the last decade, stray dogs have been significant ecological, economical and sociological problem in the world as well as in the Republic of Serbia. They occupy specific place in the ecology of big cities and their contact with human population represents danger since they are carriers of many zoonotic infectious diseases. The goal of this paper is to present epizootiological survey on some diseases of bacterial, viral and parasitic origin through serological investigation of blood sera and full blood. The prevalence of leptospirosis, Tularaemia, West Nile fever and dirofilariosis has been determined in this research. The material included full blood and blood sera of stray dogs in the wider territory of Leskovac city. The research methods encompassed standard serological tests: microscopic agglutination test (MAT) for determination of specific antibodies against Leptospira spp.; slow and fast agglutination test for determination of antibodies against Tularaemia causative agent (Francisella tularensis); agar gel immunodiffusion $(A G I D)$ for detection of specific antibodies against West Nile virus $-W N V$; modified Knot's test for the detection of microfilaria. The results revealed seropositivity for causative agents of Leptospirosis, Tularaemia

\footnotetext{
1* e-mail: ana.samokovlija@gmail.com
}

Manić Marija, DVM, research assistant, Prokić Nataša, DVM, research assistant, Vasić Ana, DVM, research assistant, Marić Jovan, DVM, research assistant, Prof. Đuričić Bosiljka, PhD, full professor, Faculty of Veterinary Medicine, University of Belgrade, DVM Gojković Katarina, Msc DVM Đorić Goran, Veterinary ambulance “Đura vet”, Manojlovce bb, Leskovac, Vojinović Dragica, DVM, PhD, Scientific Veterinary Institute of Serbia, Belgrade. 
and dirofilariosis, while there were no positive findings for WNV.

Key words: stray dogs, Leskovac, zoonoses

\title{
SEROPREVALENCE NEKIH ZARAZNIH BOLESTI U PASA LUTALICA U ŠIREM PODRUČJU LESKOVCA
}

\author{
Marija Manić ${ }^{1}$, Nataša Prokić ${ }^{1}$, Katarina Gojković ${ }^{2}$, Goran Đorićn \\ Ana Vasić ${ }^{1}$, Jovan Marić ${ }^{1}$, Dragica Vojinovićs ${ }^{3}$, Bosiljka Đuričić ${ }^{1}$ \\ ${ }^{1}$ Fakultet veterinarske medicine, Beograd \\ ${ }^{2}$ Veterinarska ambulanta "Đura vet", Leskovac \\ ${ }^{3}$ Naučni institut za veterinarstvo Srbije, Beograd
}

\section{Kratki sadržaj}

Tokom poslednjih deset godina, psi lutalice se smatraju značajnim ekološkim, ekonimskim i socijalnim problemom kako u celom svetu tako i u Republici Srbiji. Psi lutalice zauzimaju posebno mesto u ekologiji velikih gradova i njihov kontakt sa ljudima, predstavlja opasnost, jer oni mogu biti nosioci uzročnika mnogih zoonotskih infektivnih oboljenja. Cilj ovog rada je da se predstavi epizootiološka studija nekih bakterijskih, virusnih i parazitskih oboljenja, pomoću seroloških ispitivanja krvnih seruma i pune krvi pasa. Tokom ovog istrživanja, ispitivana je prevalenca na leptospirozu, tularemiju, groznicu zapadnog Nila i dirofilariozu. Materijal su predstavljali uzorci pune krvi i krvnog seruma pasa lutalica, iz šire okoline grada Leskovca. Metode ispitivanja su obuhvatale standardne serološke testove: test mikroskopske aglutinacije (MAT) za utvrđivanje specifičnih antitela protiv Leptospira spp.; spora i brza aglutinacija za utvrđivanje antitela protiv uzročnika tularaemije (Francisella tularensis); agar gel imunodifuzioni test (AGID) za detekciju specifičnih antitela protiv virusa Zapadnog Nila -WNV; modifikovani Knotov test za detekciju mikrofilarija. Rezultati ispitivanja pokazuju seropozitivnost na uzročnike leptospiroze, tularemije i dirofilarioze, dok nisu dobijeni pozitivni nalazi za WNV.

Ključne reči: psi litalice, Leskovac, zoonoze

\section{INTRODUCTION}

In past decades, the problem of stray dogs is widespread in the territory of the Republic of Serbia. The number of stray dogs in cities depends on the size of urban habitat and the number of pet owners, who produce major number 
of future stray dogs. Considering the fact that stray dogs occupy important place in the ecology of cities because they are reservoirs and vectors of many infectious diseases and that they are commonly in close contact with humans, it is of a great importance to introduce and practice control measures with the aim of disease development prevention (Beck, 1975).

Leptospirosis is one of the most common infectious, zoonotic diseases of many animal species and humans caused by different serovars of spirochetes Leptospira spp. In nature, the organism is maintained in the circle between susceptible species, reservoirs and environment. The disease can be found in acute, subacute and chronic form. Chronic infections are difficult for clinical diagnostics. They are characterized by chronic hepatitis, renal failure and abortions, along with the presence of Leptospira spp. in kidneys and genital organs of animals (Genevieve, 2006). Many different sources of infection, numerous carriers, chronically infected animals and many serovars that cause the disease have significant role in spreading, diagnostics and suppression of Leptospirosis (Dmitrović et al., 2002; Hrnjaković Cvjetković et al., 2011).

Stray dogs are important reservoirs and transmitters of Leptospirosis to human population as well as to other animal species (Vojinović et al., 2012; Vojinović et al., 2013). The presence of Leptospira spp. in the population of stray dogs can be approached with several aspects: health care of humans, health care and welfare of animals as well as from an economical and political point of view.

Tularaemia is a zoonotic infectious disease caused by Gram negative, pleomorphic, immobile, non-sporulating bacteria Francisella tularensis. In nature, Tularaemia affects lagomorph species - rabbits, but the disease is confirmed in more than 100 different domestic and wild animal species, birds, amphibians and reptiles (Ellis et al., 2002). The causative agent is relatively resistant in nature and can survive for a long time in water. Natural infections of dogs are rare. The dogs can become infected during hunting, by eating infected rodents, through bites or scratches created by contaminated teeth or claws, or with infected ticks (Feldman K.A., 2003). In majority of cases, the disease in dogs is asymptomatic; however, in rare cases there short term anorexia, mild fever, depression, swelling of mandibular lymphatic nodes, myalgia, uveitis and conjunctivitis may occur (Green E.C., 2012; Spasojević Kosić et al., 2013). The literature data describe cases of dogs' death soon after contact with infected animals (William et al., 1979).

West Nile virus- $W N V$ belongs to the genus Flavivirus, fam. Flaviviridae. It is a member of Japanese encephalitis serogroup. The virus is maintained in nature thanks to its circulation between vectors - mosquitoes (Culex spp. and Ae- 
des spp.) and hosts - birds, horses, humans and other vertebrates (Campbell et al., 2002). West Nile fever can affect large number of bird species and mammals. In horses and humans, it causes significant clinical symptoms ranging from flu-like, mild respiratory syndrome to severe neurological symptoms and death. One of the first serological proofs of WNV circulation in the Republic of Serbia was published in 1972 when the seroprevalence was established in some regions in human population (Bordjoški et al., 1972). Currently, West Nile fever is spread worldwide. Vectors and migrating birds as reservoirs play an important role in further spreading. Epizootiological research on WNV seroprevalence in different animal populations in Serbia has started in 2008. The presence of specific antibodies was determined in horses, poultry, humans and for the first time in Serbia, in dogs as well (Samokovlija et al., 2012). Total of 1076 dogs were tested in period from 2008 to 2012 applying agar gel immunodiffusion method (AGID) and in 10 dogs $(0.93 \%)$ the precipitation antibodies on WNV were found (Đuričić et al., 2013; Manić et al., 2013).

Dirofilariasis is a parasitic disease that has zoonotic character and is caused by Dirofilaria immitis and Dirofilaria repens. Mosquitoes from the genus Aedes, Culex and Anopheles are necessary vectors for spreading of this disease since one part of dirofilaria's living cycle takes place in them. The development form of parasite - microfilaria lives in the bloodstream of the host. Most common places for finding adult forms are heart cavity for D. immitis, or subcutaneous tissue for D. repens. Dirofilariosis was primarily disease characteristic for the Mediterranean basin, but, due to the climate changes, it spread out to the north, thus nowadays it can be found in middle Europe (Genchi et al., 2009). The first data suggesting the presence of dirofilariasis in Serbia (ex-Yugoslavia) were published in the 1990s (Dimitrijević S., 1999). Afterwards, the presence, seroprevalence, diagnostics, therapy and case occurrence were closely monitored in both animals and humans (Genchi et al., 2007; Rinaldi et al., 2011; Tasić et al., 2007; Savić et al., 2012; Pajković et al., 2010; Marić et al., 2013).

\section{MATERIAL AND METHOD}

The study included a total of 50 blood sera samples and 47 samples of full blood. All blood samples were taken from stray dogs that originated from the wider area of Leskovac city.

Blood sera were tested for the presence of antibodies against eight serovars of Leptospira spp.: Icterohaemorrhagiae, Canicola, Pomona, Australis, Grippotyphosa, Bataviae, Sejroe and Bratislava. To determine the presence of specific antibodies to the agents of leptospirosis, we used microscopic aggluti- 
nation test (MAT), which is considered the gold standard.

The presence of specific antibodies for $F$. tularensis was determined using fast agglutination method on microscopic slide and slow agglutination method in tubes. Commercial antigen was used (Francisella tularensis antigen, Bioveta, Czech Republic) and method was performed according to manufacturer's instructions.

WNV specific antibodies were determined using agar gel immunodiffusion method (AGID) and antigen was prepared as described in the work of Đuričić et al. (Đuričić et al., 2013).

Total of 47 samples of full blood were tested for Dirofilariasis using modified Knot's test. This is fast and reliable method for detection of microfilaria in bloodstream.

\section{RESULTS AND DISCUSSION}

The results are shown on chart 1.

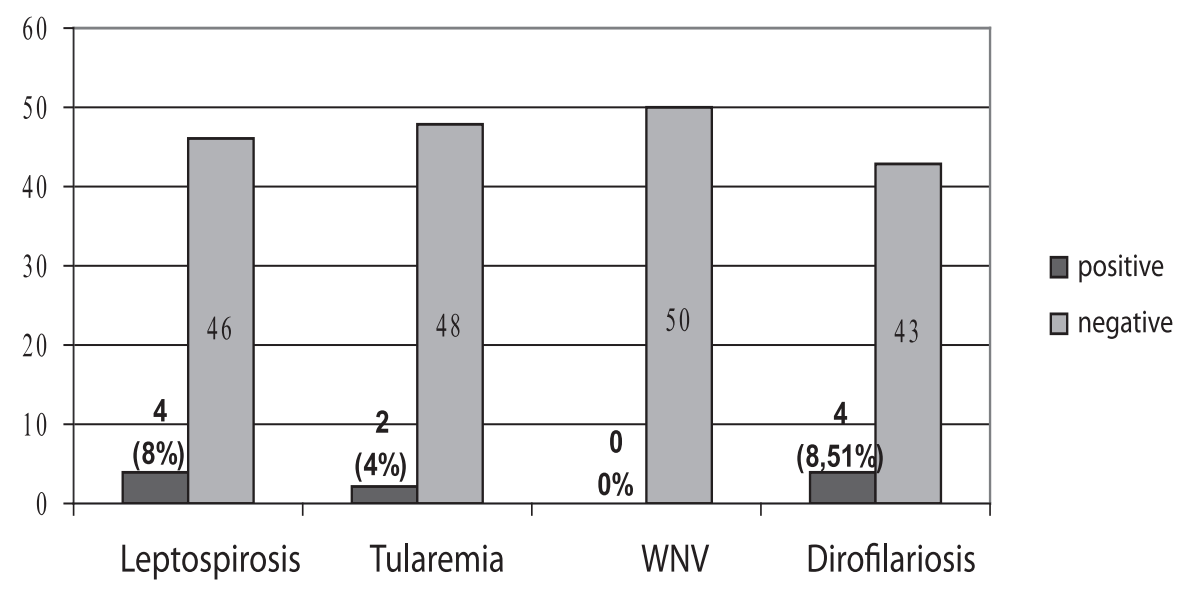

Chart 1. Seroprevalence of four infectious zoonotic diseases in stray dogs in wider territory of Leskovac city

From the total of 50 tested samples of blood sera, 4 (8\%) were tested positive for the presence of specific antibodies for Leptospira spp. All samples were positive on L. Canicola- one sample presenting borderline titre 1:100, and three samples were positive in titre 1:300. Leptospira canicola is one of the most commonly diagnosed causative agents of Leptospirosis in dogs (Vojinović et al., 2013; Manić et al., 2013). Stray dogs are very significant as reservoirs and they actively, by constant bacterial shedding in case of chronic infection, con- 
tribute to spreading and transmission of infection in human population and domestic animals.

By the use of fast agglutination method in the diagnostics of specific antibodies against Francisella tularensis, 2 positive dogs (4\%) were found. Positive samples were examined by slow agglutination method and they did not present any positivity, meaning the low titre of antibodies. Tularaemia occurs sporadically in human population in the Republic of Serbia. During the period of ten years (2000-2011), 317 human cases were registered and only one case of disease in sheep in Mladenovac area (Marić et al., 2012). Beside findings in sheep, epizootiological data for Serbia are very scarce.

There were no positive results for the presence of specific antibodies against WNV by AGID method. Dogs rarely show symptoms of WNV infection, but they show seroconversion (Samokovlija et al., 2012; Đuričić et al., 2013).

rom the total of 47 full blood samples, using modified Knot's test, 4 stray dogs $(8.51 \%)$ with microfilaria were found (figure 1). This disease has been becoming more common in dogs in Serbia in recent years (Savić et al., 2012; Pajković et al., 2010; Marić et al., 2013), impelling veterinarians and owners to perform checking for microfilaria during routine control of patients.

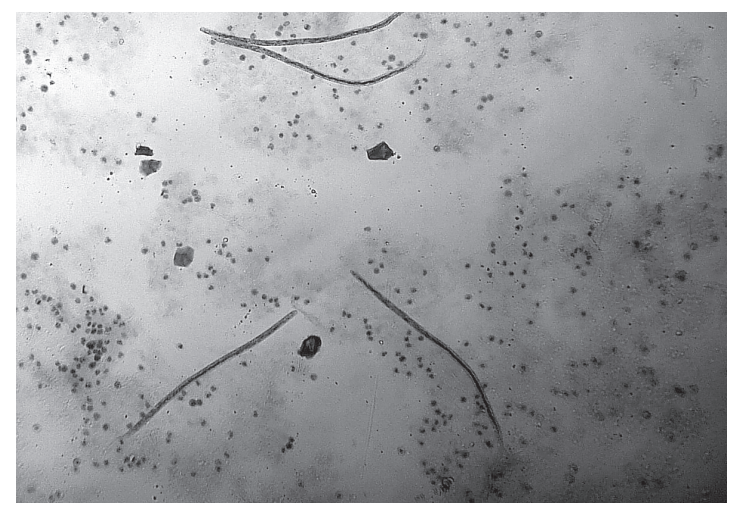

Figure 1. Modified Knot's test - microfilaria in full blood sample (Department of infectious diseases of animals and bee diseases, Faculty of Veterinary Medicine, University of Belgrade)

\section{CONCLUSION}

Considering the fact that dog shelters are one way of solving stray dog problem, the results presented in this paper are important indicator of the presence of infectious zoonotic diseases, which are underestimated in most instances. Leptospirosis is a global problem in veterinary medicine and human health care, and its presence in stray dog population poses danger for other 
animals and humans (Adler and de la Pena, 2010). Dogs are considered relatively resistant animal species to causative agent of Tularaemia. Still, the presence of seropositive dogs can be good indicator that the causative agent is present in nature in the cycle between tick as vectors, rabbits and other wild animals (Green, 2012). WNV is present in the Republic of Serbia and it circulates in nature, which was identified in epidemics in 2012 and 2013 (Popović et al., 2013), but not in dog population. The occurrence and spreading of Dirofilariosis in the Republic of Serbia is serious problem, which has to be approached from all aspects. It is necessary to establish cooperation between physicians and veterinarians, as well as between sanitary and epidemiological service. The raise of awareness is of a great importance.

\section{ACKNOWLEDGEMENT}

This paper is funded by Project TR 37015 of Ministry of education, science and technological development of the Republic of Serbia.

\section{REFERENCES}

1. Adler B., de la Pena A.M,: Leptospira and leptospirosis. Veterinary Microbiology, 140, 287-296, 2010.

2. Beck A.M.: The Public Health Implications of Urban Dogs, American Journal of Public Health, 65, 12, 1315-1318,.

3. Bordjoški M., Gligić, A., Bošković, R.: Arbovirusne infekcije u RS Srbiji. Vojnosanit. Pregl., 29, 4,173-175, 1972.

4. Campbell L Grant, Marfin A Anthony, Lanciotti S Robert, Gubler J Duane: West Nile virus. Infectious Diseases, 2, 519-529, 2002.

5. Dimitrijević S.: Dirofilarioza ante portas. In: Clinica Veterinaria 1. Proceedings, pp 58, 1999.

6. Dmitrović R., Obradović M., Nedić LJ., Đerković V., Antonijević B., Pavlović N., Babić-Dunić V., Peklar P., Trbojević R., Gligić A., Jermolenko G., Vojinović D., Radosavljević M.: Zoonoze - zdravstveni problem na području Beograda. U: Dani Zavoda 2002 XIX Stručna konferencija, Beograd, str.57-72, 2002.

7. Đuričić Bosiljka, Vasić Ana, Rogožarski D., Vojinović Dragica, Elezović Radovanović Milica, Manić Marija, Marić J., Prokić Nataša, Ilić Živka, Novotny N., Gligić Ana: Seroepizootiological - epidemiological investigation and mapping of West Nile infection in the Republic of Serbia. Acta veterinaria, 63, 5-6, 569-579, 2013. 
8. Ellis Jill, Oyston C. F. Petra, Green Michael, Titball W. Richard.: Tularaemia. Clinical microbilogy reviews, 631-646, Oct 2002.

9. Feldman Katherine Anne: Tularaemia . JAVMA, 222, 6, 725-730. March 15,2003

10. Genchi Claudio, Rinaldi Laura, Cringoli Giuseppe: Dirofilaria immitis and D. repens in dog and cat and human infections. Mappe parassitologiche, 8, 2007.

11. Genchi C., Rinaldi L., Mortarino M., Genchi M., Cringoli G.: Climate and dirofilaria infection in Europe, Veterinary Parasitology, 163, 4, 286-92, 2009.

12. Genevieve Andre-Fontaine: Canine leptospirosis-Do we have a problem? Veterinary Microbiology, 117, 19-24. 2006.

13. Greene E.Craig: Infectious Diseases of the Dog and Cat - 4th Edition, Chapter 46 - Francisella and Coxiella Infections. 476-482, 2012.

14. Hrnjaković Cvjetković Ivana, Milošević Vesna, Jerant Patić Vera, Mikić Sandra Stefan, Cvjetković D., Radovanov Jelena, Kovačević Gordana: Najčešće bakterijske zoonoze u ljudi u Vojvodini u periodu 2005-2009. Arhiv veterinarske medicine, 4, 1, 11-18, 2011.

15. Manić Marija, Vojinović Dragica, Vasić Ana, Elezović Radovanović Milica, Prokić Nataša, Marić Jovan, Rogožarski D., Đuričić Bosiljka: Seroprevalence of some infectious diseases in stray dogs in the Republic of Serbia. Материалы международной научно-практической конференции "Актуальные вопросы постдипломного образования в ветеринарной медицине” Издательство: ФГОУ ВПО Волгоградский ГАУ “Нива", 3-9, 2013.

16. Marić J., Obrenović J., Milković M., Samokovlija A., Elezović M., Ljubić B., Stevanović G., Đuričić Đ. Đuričić B.: Tularemija u Republici Srbiji u periodu 2000-2011. godine. Vet. glasnik, 66, 5-6, 463 - 472, 2012.

17. Marić J., Simić V., Medić S., Nadaškić M., Manić Marija, Prokić Nataša, Pavlović I.: Presence of dogs microfilaria on wider territory of Belgrade. In: Proceedings of Third international epizootiology days and XV Serbian epizootiology days, Niška banja, 8-11 May 2013., urednik Tamaš Petrović, pp188-192, 2013.

18. Pajković D., Savić Sara, Veljković P., Grgić Ž.: Praćenje pojave dirofilarioze kod radnih pasa u službi vojske Srbije. Arhiv veterinarske medicine, vol.3, br.2, str.53-58, 2010.

19. Popović N, Milošević B, Urošević A, Poluga J, Lavadinović L, Nedelijković J, et al. Outbreak of West Nile virus infection among humans in Serbia, August to October 2012 . Euro Surveill. 2013;18(43):pii=20613. Available from: http://www.eurosurveillance.org/ViewArticle.aspx?ArticleId=20613 20. Rinaldi L., Genchi C., Musella V., Genchi M., Cringoli G.: Geographical 
information systems as a tool in the control of heartworm infections in dogs and cats. Veterinary Parasitology 176, pp 286-290, 2011.

21. Samokovlija Ana, Vojinović Dragica, Rogožarski D., Elezović Milica, Marić J., Gligić Ana, Đuričić Bosiljka: Epizootiological and serological investigation of West Nile fever in central part of Serbia during 2011. In: Proceedings of II International epizootiology days, Beograd, 18-21 April 2012., urednik Tamaš Petrović, 55-59, 2012.

22. Savić S., Vidić B., Grgić Ž., Jurišić A., Curčić V., Ruzić M., Lolić Z.: Vektorske zoonoze pasa u Vojvodini. Arhiv veterinarske medicine, 5, 1, 77-87, 2012.

23. Spasojević Kosić Lj., Savić S.: Zdravstvena zastita lovačkih pasa. Vet. Glasnik, 67, 3-4, 259 - 268, 2013.

24. Tasić A., Tasić S., Miladinović-Tasić N., Zdravković D., Đorđević J.: Dirofilaria repens - potencijalna opasnost po zdravlje ljudi. Acta Medica Medianae, 46, 3, 52-55, 2007.

25. Vojinović D., Samokovlija A., Elezović M., Manić M., Prokić N., Maric J., Smiljanić J., Grgić Ž.: Results of representation Leptospira spp. with special reference to Leptospira bratislava in population street dogs in certain regions of the Republic Serbia. In: Proceedings of Third international epizootiology days and XV Serbian epizootiology days, Niška banja, 8-11 May 2013., urednik Tamaš Petrović. ISBN 978-86-81043-68-4, 72-76, 2013.

26. Vojinović D., Samokovlija A., Elezović M., Rogožarski D., Đuričić B.: Determination of specific antibodies against Leptospira spp. in population of stray dogs in the Republic of Serbia, Eurolepto 2012, Fakultet veterinarske medicine Sveučilišta u Zagrebu, 978-953-6062-87-4, http://www.vef. unizg.hr/eurolepto2012/prg.php, 2012.

27. William J. Martone, Lewis W. Marshall, Arnold F. Kaufmann, Jesse H. Hobbs, Martin E. Levy: Tularaemia Pneumonia in Washington. DC. A Report of Three Cases With Possible Common-Source Exposures. JAMA. 242:2315-2317, 2315-2317, 1979.

Primljeno: 15.05.2014.

Odobreno: 08.07.2014. 